\title{
Negative energy balance in dairy cows is associated with specific changes in IGF-binding protein expression in the oviduct
}

\author{
M A Fenwick, S Llewellyn, R Fitzpatrick ${ }^{1}$, D A Kenny ${ }^{2}$, J J Murphy ${ }^{3}$, J Patton ${ }^{3}$ and D C Wathes \\ Reproduction, Genes and Development Group, Department of Veterinary Basic Sciences, Royal Veterinary College, \\ London, AL9 7TA, UK, ${ }^{1}$ Animal Production Research Centre, Mellows Campus, Athenry, Co. Galway, Ireland, \\ ${ }^{2}$ School of Agriculture, Food Science and Veterinary Medicine, University College, Dublin, Ireland and ${ }^{3}$ Teagasc \\ Moorepark, Dairy Production Research Centre, Fermoy, Co. Cork, Ireland
}

Correspondence should be addressed to D C Wathes; Email: dcwathes@rvc.ac.uk

M A Fenwick and S Llewellyn contributed equally to this work

\begin{abstract}
Negative energy balance (NEB) during early lactation in dairy cows leads to an altered metabolic state that has major effects on the production of IGF family members. Low IGF-I concentrations are associated with poor fertility and therefore we aimed to determine whether NEB exerts a direct effect on IGF expression in the postpartum oviduct. Multiparous Holstein cows were allocated to two treatments (each $n=6$ ) designed using differential feeding and milking regimes to produce either mild NEB (MNEB) or severe NEB (SNEB). Animals were slaughtered in week 2 of lactation when divergent metabolic profiles were evident. Oviducts were collected for RNA analysis by real-time RT-PCR and in situ hybridisation. Quantitative measures in oviduct gene expression were obtained for all members of the IGF family (IGF-I/II, IGF-binding proteins (IGFBP) 1-6 and receptors for IGF types 1 and 2), insulin A/B, GH, glucocorticoid and oestrogen $\alpha / \beta$. Expression of IGFBP-2 and IGFBP-6 (both of which have a high affinity for IGF-II) was decreased in SNEB relative to MNEB $(P<0.05)$. No other gene was altered by NEB, but IGF-II, IGFBP-3, IGFBP-5 and IGFBP-6 all showed differential expression in different regions of the oviduct. These results indicate that, in addition to low circulating IGF-I after calving, NEB may also influence IGF availability in the oviduct indirectly through changes in specific IGFBP expression. It is possible that the predicted increased signalling by IGF-II may perturb embryo development, contributing to the high rates of embryonic mortality in dairy cows.

Reproduction (2008) 135 63-75
\end{abstract}

\section{Introduction}

Modern high-yielding dairy cows enter a state of negative energy balance (NEB) around calving when the energy demand for maintenance and lactation exceeds that of dietary energy intake (Bauman \& Currie 1980). Cows with excessive body tissue mobilisation at this stage may take up to 20 weeks to regain a positive energy balance status (Taylor et al. 2003). Although the resumption of ovarian activity is initiated during NEB (Beam \& Butler 1999), there are subsequent effects on fertility that lead to poor conception rates (Wathes et al. 2003, 2007). Previous studies have examined possible effects of NEB on the oocyte (e.g. Leroy et al. 2006), ovary (e.g. Llewellyn et al. 2007) and uterus (e.g. Butler 2001) but work on the oviduct is limited, although it provides a crucial environment for gamete transport, sperm capacitation, fertilisation and early embryonic development (Ellington 1991, Hunter 2003). In a normal cyclic animal, the secretory activity of the oviduct increases during the periovulatory period and early luteal phase (Murray 1995, Buhi et al. 2000), so that proteins are expressed on the epithelial apical surface or released into the oviductal lumen, which can enhance both sperm survival (Boilard et al. 2004) and embryo development (Lai et al. 1996). Such secretory activity is decreased during the luteal phase and pregnancy, thought to be due to the prevailing high concentration of progesterone (Nayak et al. 1976), but resumes following parturition (Seki et al. 1978, Cigankova et al. 1996).

Previous work has shown that amongst the metabolites and metabolic hormones that change in relation to NEB, insulin-like growth factor-I (IGF-I) is strongly associated with the calving to conception interval and pregnancy outcome (Wathes et al. 2003, Taylor et al. 2004a). The nutritional sensitivity of IGF-I is widely reported (Thissen et al. 1994) and we and others have shown that severe NEB (SNEB) during early lactation attenuates gene transcription of IGF-I and also a number of IGF-related members in the liver, producing an endocrine environment of reduced 
IGF-I stability and bioavailability (Lucy et al. 2001, Fenwick et al. 2006). IGFs have a broad range of functions to promote differentiation, stimulate mitogenesis and inhibit apoptosis (Jones \& Clemmons 1995). The IGF system comprises a second ligand (IGF-II), two receptors (IGF-1R and IGF-2R) and at least six binding proteins (IGFBP). This complexity serves to enable differential regulation of the IGF system within different tissues (Clemmons 1997).

Transcripts for IGF-I and IGF-II have been detected in the oviduct of ruminants (Schmidt et al. 1994, Stevenson \& Wathes 1996), primates (Gabler et al. 1998) and rodents (Carlsson et al. 1993). Specific localisation studies have further shown that IGF-I expression mainly predominates in the mucosa and IGF-II in the muscularis (Pfeifer \& Chegini 1994, Pushpakumara et al. 2002). Purified isolates of oviductal epithelial cells produce and secrete both IGF-I and IGF-II (Wiseman et al. 1992) as well as the regulatory binding proteins IGFBP-2 and IGFBP-3 (Giudice et al. 1992). IGF-I and IGF-II in a variety of species are generally regulated in a positive manner with ovarian oestradiol production (Wiseman et al. 1992, Carlsson et al. 1993, Stevenson \& Wathes 1996, Gabler et al. 1998). The presence of an IGF system in the oviduct suggests that the IGFs may act as important modulators of oviductal function.

For many tissue types, support and maintenance rely on the presence of an adequate IGF system which may be derived from both an endocrine source like the liver or produced locally in a paracrine/autocrine manner. Circulating IGF-I concentrations fall in the immediate postpartum period in dairy cows and may not return to pre-partum levels for more than 12 weeks in some cows (Taylor et al. 2004a). Restoration of oviductal activity therefore occurs in an endocrine environment of low IGF-I. Waves of follicular activity resume after about 10-14 days (Roche \& Diskin 2001) but progesterone concentrations remain low until after the first ovulation. In dairy cows from the same herd as that used for the present study, the interval to commencement of luteal activity was $31 \pm 15$ days (mean \pm s.D.) and was shorter in cows having higher IGF-I concentrations in the first 2 weeks after calving (Patton et al. 2007). The uterus is also undergoing involution during this period, a process which is normally complete in $30-50$ days (Gier \& Marion 1968). Microbial contamination of the bovine uterus is almost universal during the first week postpartum, and the rate of bacterial clearance also affects the return to normal cyclicity (Sheldon et al. 2006).

At present, virtually nothing is known about the potential regulatory effects of NEB on oviduct function and we postulated that the global effects of NEB might influence local gene expression during the recovery period. The specific aims of this study were thus to determine the effects of NEB on oviductal IGF transcript expression during the early postpartum interval.

\section{Results}

\section{Metabolic and hormonal effects of NEB}

Results are reported for the day of tissue collection, which was on days 6-7 of the first follicular wave after calving, that is, before any cow had ovulated. This occurred on days $14 \pm 0.7$ postpartum ( $n=6$, ranges $11-16)$ in the mild NEB (MNEB) group and days $14 \pm 0.7$ postpartum ( $n=6$, ranges $12-16)$ in the SNEB group. Exposing cows to a regime of differential milking frequency and dietary intake during the first 2 weeks postpartum produced two groups with altered metabolic indices at the time of tissue collection (Table 1), although average daily milk yield at the time of sample collection did not differ between groups (21.7 \pm $0.83 \mathrm{~kg}, n=12)$. This is because the SNEB cows were simultaneously stimulated to produce extra milk by $3 \times$ milking, and limited in their potential for additional milk production by the dietary energy restriction. This resulted in a SNEB and large degree of body tissue mobilisation, as evidenced from the blood metabolite data. Concentrations of circulating IGF-I $(P=0.001)$ and glucose $(P=0.001)$ were lower in SNEB relative to MNEB cows, while non-esterified fatty acids (NEFA; $P=0.007)$ and $\beta$-hydroxybutyrates (BHB; $P=0.001$ ) concentrations were elevated. Urea concentrations tended to be higher in the SNEB cows $(P=0.075)$. These differences were reflected in the actual energy balance calculations, which tended to be lower in the SNEB group $(P=0.079)$.

Plasma concentrations of $\mathrm{GH}$, insulin, oestradiol and cortisol did not differ significantly between the two groups $(P>0.1)$. At the time of tissue collection, the sizes of the dominant follicles were also similar: $15.0 \pm 0.69$ and $12.2 \pm 1.25 \mathrm{~mm}$ respectively in the MNEB and SNEB groups. The diameter of the

Table 1 Concentrations of hormones and metabolic factors in serum of negative energy balance (NEB) cows at the time of tissue sampling.

\begin{tabular}{lccc}
\hline & $\begin{array}{c}\text { Mild NEB } \\
(n=6)\end{array}$ & $\begin{array}{c}\text { Severe NEB } \\
(n=6)\end{array}$ & Difference $(P)$ \\
\hline $\begin{array}{l}\text { Endocrine } \\
\text { IGF-I (ng/ml) }\end{array}$ & $51 \pm 8.4$ & $11 \pm 1.1$ & \\
Insulin & $0.22 \pm 0.058$ & $0.13 \pm 0.019$ & 0.001 \\
$(\mu \mathrm{IU} / \mathrm{ml})$ & & & 0.178 \\
Oestradiol & $2.2 \pm 0.33$ & $1.6 \pm 0.24$ & 0.137 \\
$(\mathrm{pg} / \mathrm{ml})$ & & & \\
GH (ng/ml) & $18 \pm 8.0$ & $9 \pm 0.7$ & 0.319 \\
Cortisol & $13 \pm 5.7$ & $5 \pm 1.6$ & 0.239 \\
$(\mathrm{nmol} / \mathrm{l})$ & & & \\
Metabolism & & & \\
EB UFL per day & $-2.7 \pm 1.41$ & $-6.1 \pm 1.03$ & 0.079 \\
NEFA (mM) & $0.55 \pm 0.216$ & $1.41 \pm 0.136$ & 0.007 \\
BHB (mM) & $0.59 \pm 0.097$ & $3.71 \pm 0.201$ & $<0.001$ \\
Glucose (mM) & $4.1 \pm 0.13$ & $2.7 \pm 0.15$ & $<0.001$ \\
Urea (mM) & $4.0 \pm 0.46$ & $5.1 \pm 0.31$ & 0.075 \\
\hline
\end{tabular}

Values are mean \pm s.E.M. $\mathrm{GH}$, growth hormone; $\mathrm{EB}$, energy balance; NEFA, non-esterified fatty acid; BHB, $\beta$-hydroxybutyrate. 
previously gravid uterine horn was larger than that of the previously non-gravid uterine horn $(59 \pm 6.4$ and $33 \pm 2.2 \mathrm{~mm}$ respectively, mean \pm s.E.M., $P=0.005$ ), but these measurements did not differ between groups. This large difference between horns indicates that, as expected, uterine involution was not yet complete at this stage.

\section{Effect of NEB on the expression of IGF family members and related hormone receptors in the oviduct}

The real-time RT-PCR data, based on whole oviducts, revealed that expression of IGFBP-2 and IGFBP-6 was significantly lower in the SNEB cows (Table 2). There were no other differences according to EB status for other members of the IGF family or in the other receptors examined (insulin receptor type $A / B, I R-A / B$, oestrogen receptor $\alpha / \beta, E R \alpha / \beta$, glucocorticoid receptor $\alpha, G R \alpha$ and growth hormone receptor, GHR). The concentration of 18SrRNA measured was similar between groups. IGF-2R was only detected in 3 out of 12 oviducts, and IGFBP- 1 was undetectable in 10 out of 12 samples (data not shown). These findings were closely confirmed by analysis of the in situ hybridisation data from the opposite oviduct (Table 3). Using this technique, there was a highly significant $(P=0.009)$ reduction in IGFBP-6 expression in the SNEB cows, and a strong tendency towards reduced IGFBP-2 expression in the same cows $(P=0.068)$. Overall, levels of the IGFBP-6 transcript were reduced in SNEB cows by more than twofold relative to MNEB cows as detected by both real-time PCR and in situ hybridisation. No other members of the IGF family examined showed significant differences according to EB status.

Table 2 Expression levels of mRNA in oviduct of lactating cows maintained under mild or severe negative energy balance.

\begin{tabular}{lccc}
\hline Gene & Mild NEB & Severe NEB & Difference $(P)$ \\
\hline IGF-I & $4.4 \pm 1.01$ & $3.3 \pm 1.71$ & 0.415 \\
IGF-II & $4.7 \pm 0.73$ & $3.8 \pm 0.79$ & 0.455 \\
IGF-1R & $0.6 \pm 0.17$ & $0.5 \pm 0.20$ & 0.615 \\
IGF-2R & $\mathrm{ND}$ & $\mathrm{ND}$ & - \\
IGFBP-1 & $\mathrm{ND}$ & $\mathrm{ND}$ & - \\
IGFBP-2 & $0.2 \pm 0.06$ & $0.1 \pm 0.03$ & 0.038 \\
IGFBP-3 & $3.9 \pm 0.48$ & $2.4 \pm 0.51$ & 0.051 \\
IGFBP-4 & $1.3 \pm 0.12$ & $1.3 \pm 0.26$ & 0.775 \\
IGFBP-5 & $3.7 \pm 0.35$ & $5.5 \pm 1.16$ & 0.170 \\
IGFBP-6 & $4.4 \pm 0.91$ & $1.7 \pm 0.58$ & 0.029 \\
IR-A & $0.6 \pm 0.12$ & $0.6 \pm 0.10$ & 0.851 \\
IR-B & $0.2 \pm 0.03$ & $0.2 \pm 0.05$ & 0.971 \\
GHR & $0.5 \pm 0.15$ & $0.3 \pm 0.19$ & 0.398 \\
GR $\alpha$ & $2.1 \pm 0.66$ & $1.3 \pm 0.50$ & 0.430 \\
ER $\alpha$ & $21.9 \pm 2.48$ & $23.6 \pm 3.75$ & 0.756 \\
ER $\beta$ & $8.0 \pm 2.97$ & $6.0 \pm 2.67$ & 0.625 \\
I8SrRNA & $64.5 \pm 11.36$ & $69.2 \pm 10.94$ & 0.865 \\
\end{tabular}

Values are means \pm s.E.M. Values are expressed in fg/ $\mu$ g RT RNA, except

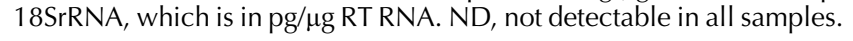

\section{Localisation of IGFs in the oviduct}

Localisation patterns within the oviduct are illustrated in Figs 1 and 2 and a summary of the expression of measured traits according to region is presented in Table 3. Isthmus was not present in oviduct sections from three cows in each group. IGF-I mRNA was localised to the luminal epithelium of the oviduct by in situ hybridisation, and expression levels did not vary between the ampulla, isthmus and infundibulum. IGF-II expression was found in the muscle and mucosa of all three oviductal regions and transcript levels were relatively higher in the isthmus compared with the ampulla and infundibulum $(P=0.001)$. IGF-1R was detectable in the mucosa of all oviduct regions and no regional differences were evident. IGF-2R could not be reliably detected by this method (data not shown).

Expression of IGFBP-1 was likewise not detectable in the bovine oviduct by in situ hybridisation. IGFBP-2 hybridisation was evenly dispersed across the smooth muscle and mucosal layers in all regions. Strong antisense hybridisation was also noted in the outer adventitia (Fig. 2a). Expression of IGFBP-3 and IGFBP4 mRNA was also evenly detectable in muscle and mucosal layers. Spatially, IGFBP-3 expression was higher in the isthmus than the infundibulum $(P=0.035)$, with a similar trend for IGFBP-4 $(P=0.056)$. IGFBP-5 mRNA was localised with relatively higher expression in the muscle layer and the isthmus region compared with the remainder of the oviduct $(P=0.004$; Fig. $2 \mathrm{~g})$. A region $\times$ treatment interaction for IGFBP- 6 mRNA indicated reduced levels of expression in the ampulla of SNEB cows relative to that of MNEB cows (optical density OD units SNEB $0.136 \pm 0.055$ and MNEB $0.327 \pm 0.054$; $P=0.006)$. There was strong intensity labelling in the mucosal aspect of the oviduct wall (Fig. 2i) with relatively higher levels in the ampulla and infundibular regions $(P=0.001)$.

\section{Gene expression relationships in the postpartum oviduct}

When values obtained from quantitative RT-PCR were considered regardless of treatment, a number of traits were identified that exhibited positive relationships in the postpartum oviduct (Fig. 3; all $P=0.01$ ). In particular, expression levels of IGF-I and GHR were strongly associated with each other $(r=0.921)$ and levels of both of these gene transcripts were individually associated with IGF-1R and ER $\beta$ (see Fig. 3). Expression of the IGF-I transcript was also associated with IGF-II and $G R \alpha$ transcript levels and GHR was associated with IGFBP-6 transcript levels. ER $\beta$ levels were positively associated with GR $\alpha(r=0.912)$ and IGF-1R $(r=0.761)$, while IR-B levels were positively associated with IR-A 
Table 3 Expression of the insulin-like growth factor (IGF) system by in situ hybridisation in oviduct tissue of the dairy cow during negative energy balance (NEB).

\begin{tabular}{|c|c|c|c|c|c|c|c|c|c|}
\hline \multirow[b]{2}{*}{ Probe } & \multicolumn{5}{|c|}{ Region } & \multicolumn{2}{|c|}{ Treatment } & \multicolumn{2}{|c|}{ Difference $(P)$} \\
\hline & Isthmus & Ampulla & Infundibulum & Muscle & Mucosa & mNEB & sNEB & Region & Treatment \\
\hline IGF-I & $0.047 \pm 0.015$ & $0.057 \pm 0.013$ & $0.046 \pm 0.016$ & - & + & $0.058 \pm 0.020$ & $0.042 \pm 0.018$ & 0.298 & 0.566 \\
\hline IGF-II & $0.104 \pm 0.008^{\mathrm{a}}$ & $0.077 \pm 0.006^{\mathrm{b}}$ & $0.078 \pm 0.009^{b}$ & + & + & $0.089 \pm 0.009$ & $0.084 \pm 0.009$ & $\leq 0.001$ & 0.669 \\
\hline IGF-1R & $0.042 \pm 0.007$ & $0.052 \pm 0.004$ & $0.050 \pm 0.007$ & - & + & $0.047 \pm 0.005$ & $0.049 \pm 0.006$ & 0.320 & 0.854 \\
\hline IGFBP-2 & $0.043 \pm 0.008$ & $0.052 \pm 0.005$ & $0.054 \pm 0.008$ & + & + & $0.061 \pm 0.008$ & $0.039 \pm 0.008$ & 0.365 & 0.068 \\
\hline IGFBP-3 & $0.125 \pm 0.013^{\mathrm{a}}$ & $0.103 \pm 0.011^{\mathrm{ab}}$ & $0.096 \pm 0.014^{b}$ & + & + & $0.103 \pm 0.016$ & $0.114 \pm 0.016$ & 0.035 & 0.645 \\
\hline IGFBP-4 & $0.064 \pm 0.009$ & $0.046 \pm 0.007$ & $0.042 \pm 0.011$ & + & + & $0.061 \pm 0.009$ & $0.040 \pm 0.010$ & 0.056 & 0.125 \\
\hline IGFBP-5 & $0.119 \pm 0.013^{\mathrm{a}}$ & $0.085 \pm 0.010^{b}$ & $0.086 \pm 0.014^{\mathrm{b}}$ & ++ & - & $0.089 \pm 0.015$ & $0.105 \pm 0.015$ & 0.004 & 0.447 \\
\hline IGFBP-6 & $0.078 \pm 0.030^{b}$ & $0.216 \pm 0.024^{\mathrm{a}}$ & $0.212 \pm 0.034^{\mathrm{a}}$ & + & ++ & $0.245 \pm 0.034^{x}$ & $0.092 \pm 0.035^{y}$ & $\leq 0.001$ & 0.009 \\
\hline
\end{tabular}

Values are mean \pm S.E.M. optical density units analysed by linear mixed model. $n=6$ cows per treatment group; isthmus was not present in oviduct sections from three MNEB and three SNEB cows. $+/-$ symbols indicate relative intensity of hybridisation where ++ is strong, + is weak, and - is no specific hybridisation. ${ }^{\text {ab } W i t h i n ~ r o w s, ~ v a l u e s ~ w i t h ~ d i f f e r e n t ~ s u p e r s c r i p t s ~ a r e ~ s i g n i f i c a n t l y ~ d i f f e r e n t ~ b e t w e e n ~ o v i d u c t ~ r e g i o n s . ~}{ }^{x y}$ Within rows, values with different superscripts are significantly different between energy balance treatment groups.
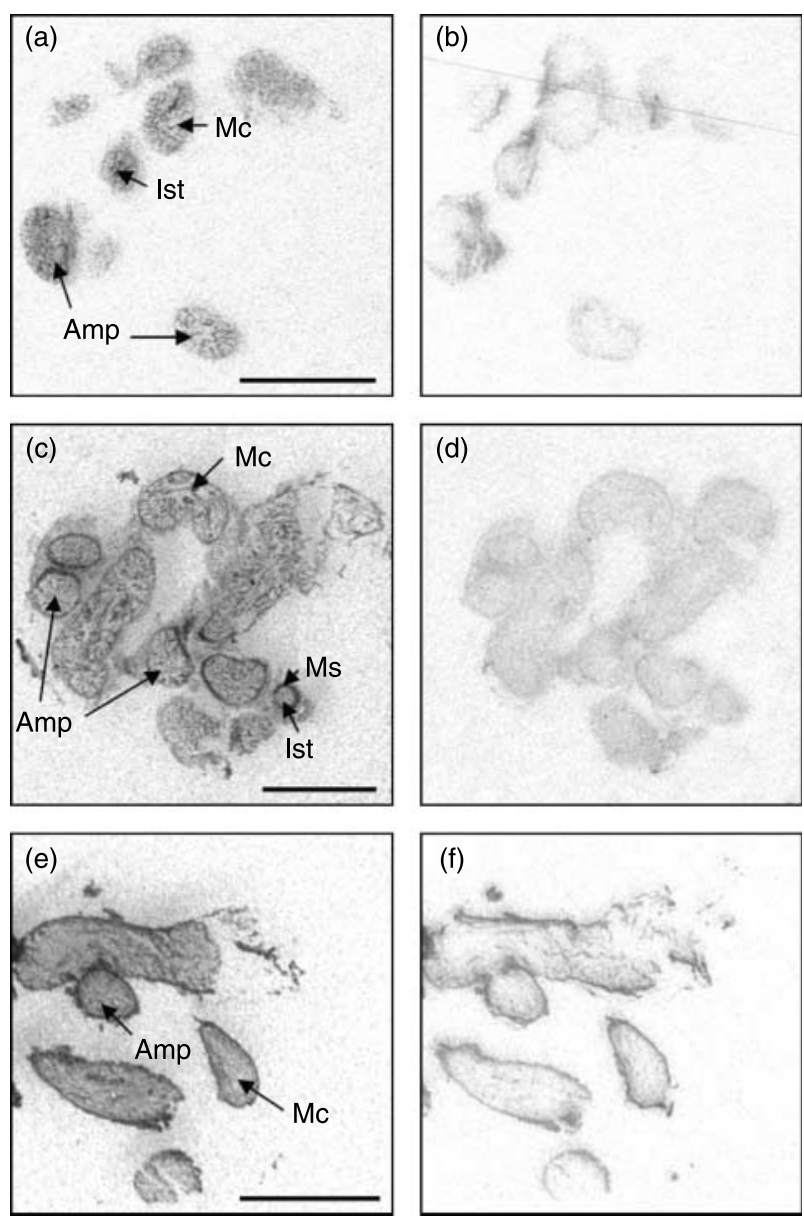

Figure 1 Expression of IGF mRNA by in situ hybridisation in the oviduct of postpartum dairy cows in negative energy balance. Autoradiographic localisation of IGF-I (a and b), IGF-II (c and d) and IGF-1R (e and f). Examples of antisense ( $a, c$ and e) and sense $(b, d$ and $f$ ) probes are illustrated. Amp, ampulla; Ist, isthmus; Ms, muscularis; Mc, mucosa. Scale bars $=5 \mathrm{~mm}$. $(r=0.835)$ and IGFBP-5 $(r=0.772)$ (all $P=0.01$, not shown). No relationships were detected between gene expression and circulating oestradiol concentrations in individual cows.

\section{Discussion}

Previous studies have indicated that members of the IGF family are expressed in the oviduct and are regulated by stage of the oestrous cycle (Carlsson et al. 1993, Gabler et al. 1998, Pushpakumara et al. 2002) yet little is known about the effect of energy balance on the regulation of IGFs in this important tissue. In our model of NEB, results show that neither the local production of IGF-I or IGF-II, nor any of the receptors associated with these ligands were affected by the different NEB regimes. By contrast, a comparative reduction in IGFBP-2 and IGFBP-6 mRNA was evident in oviducts from SNEB relative to MNEB cows. The net effect of these changes suggests that NEB may influence oviductal recovery and function postpartum by disrupting the balance of local IGF availability, rather than by having a direct affect on local IGF synthesis. Dairy cows are normally inseminated again from about 50-60 days after calving, whereas the time of sample collection at 2 weeks postpartum in this study was much earlier. This is a physiologically relevant time to investigate as it is close to the nadir in energy balance that occurs after calving and it also enabled samples to be collected without the likely confounding effect of differences in the stage of the oestrous cycle. Furthermore, high-yielding animals can take up to 20 weeks to regain a positive energy balance status after calving (Taylor et al. 2003). Their continued low circulating IGF-I concentrations over this period (Taylor et al. 2004a) suggests that the changes to the oviductal IGF system reported here may still be present during the service period in some cows.

The liver is the major source of IGF-I and IGF-II in the circulation (Zapf \& Froesch 1986). In our model, the production of hepatic IGF-I was severely restricted in 

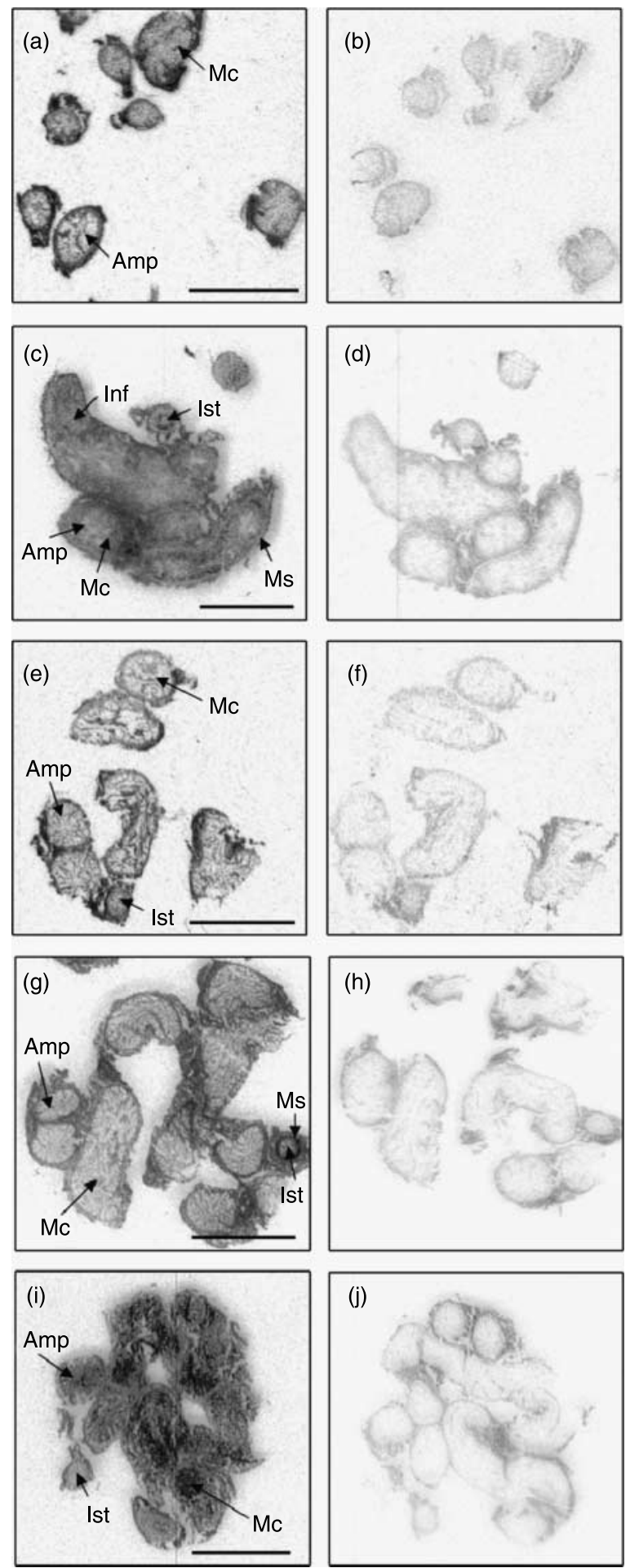

Figure 2 Expression of IGFBP mRNA by in situ hybridisation in the oviduct of postpartum dairy cows in negative energy balance. Autoradiographic localisation of IGFBP-2 (a and b), IGFBP-3 (c and d), IGFBP-4 (e and f), IGFBP-5 (g and $h$ ) and IGFBP-6 ( $i$ and $j$ ).

Examples of antisense (a, c, e, g and i) and sense (b, d, f, h and j) probes are illustrated. Amp, ampulla; Ist, isthmus; Inf, infundibulum; Ms, muscularis; Mc, mucosa. Scale bars $=5 \mathrm{~mm}$.
SNEB cows in association with a reduction in GHR but hepatic IGF-II mRNA was not significantly changed, so the ratio of IGF-II:IGF-I mRNA within the liver was increased. These data are consistent with those of others which showed a decline in GHR and IGF-I in the periparturient period (Radcliff et al. 2003). Circulating IGF-II was not measured in the present experiment, but concentrations of IGF-II were about fourfold higher than those of IGF-I during pregnancy in heifers, and showed a lesser response to alterations in dietary protein (Perry et al. 2002). In our animals, these changes occurred alongside elevated hepatic concentrations of IGFBP-2 mRNA and a reduction in both IGFBP-3 and the acidlabile subunit (Fenwick et al. 2006).

One assumption is that, under these circumstances, IGFBP-2 forms a binary complex with IGF-II in order to facilitate circulatory transport to peripheral tissues and allow translocation of IGF-II through the capillary endothelium (Bar et al. 1990). Within the oviduct, there was local expression of both IGF-I and IGF-II mRNAs, although in this tissue neither differed in relation to EB status. Oestradiol appears to be the major regulator of IGF-I within the reproductive tract (Murphy \& Friesen 1988) and in oviduct IGF-I mRNA increases at oestrus (Stevenson \& Wathes 1996). In rats, $\mathrm{GH}$ can also increase uterine IGF-I expression (Murphy \& Friesen 1988) although Pershing et al. (2002) could detect no effect of bovine somatotrophin (bST) treatment on bovine endometrial IGF-I expression. However, in this latter experiment, bST did increase IGF-II mRNA in the oviduct on day 3 of the cycle. Our results across EB groups showed highly significant positive correlations between RT-PCR values for IGF-I, ER $\beta$ and GHR mRNAs, suggesting that both oestradiol and $\mathrm{GH}$ may be involved in the control of oviductal IGF-I production. The IGF-I mRNA concentration was also highly correlated with that of the glucocorticoid receptor. Follicular fluid contains high concentrations of cortisol, and it has been suggested that when this is released at ovulation it may influence the activity of the oviduct (Yding Anderson 2002). In late pregnant ewes, the surge release of cortisol induces a switch from IGF-II to IGF-I expression in foetal liver (Fowden 1995), but this effect has not, to our knowledge, been investigated in the reproductive tract.

Previous evidence suggests that expression of IGF-I in the bovine oviduct is comparatively low, with greater production of IGF-II (Watson et al. 1999, Pershing et al. 2002). Isolated oviduct epithelial cells are capable of producing large amounts of IGF-II in culture (Wiseman et al. 1992, Xia et al. 1996, Winger et al. 1997), and in the pig IGF-II levels in the oviductal fluid fluctuate in a cyclical manner and reach a peak just prior to oestrus (Wiseman et al. 1992). Given the intrinsic ability of IGF-II to stimulate mitogenesis and prevent apoptosis, locally produced IGF-II may promote proliferation and metabolic activity of the oviduct itself (Tieman \& Hansen 1995) 

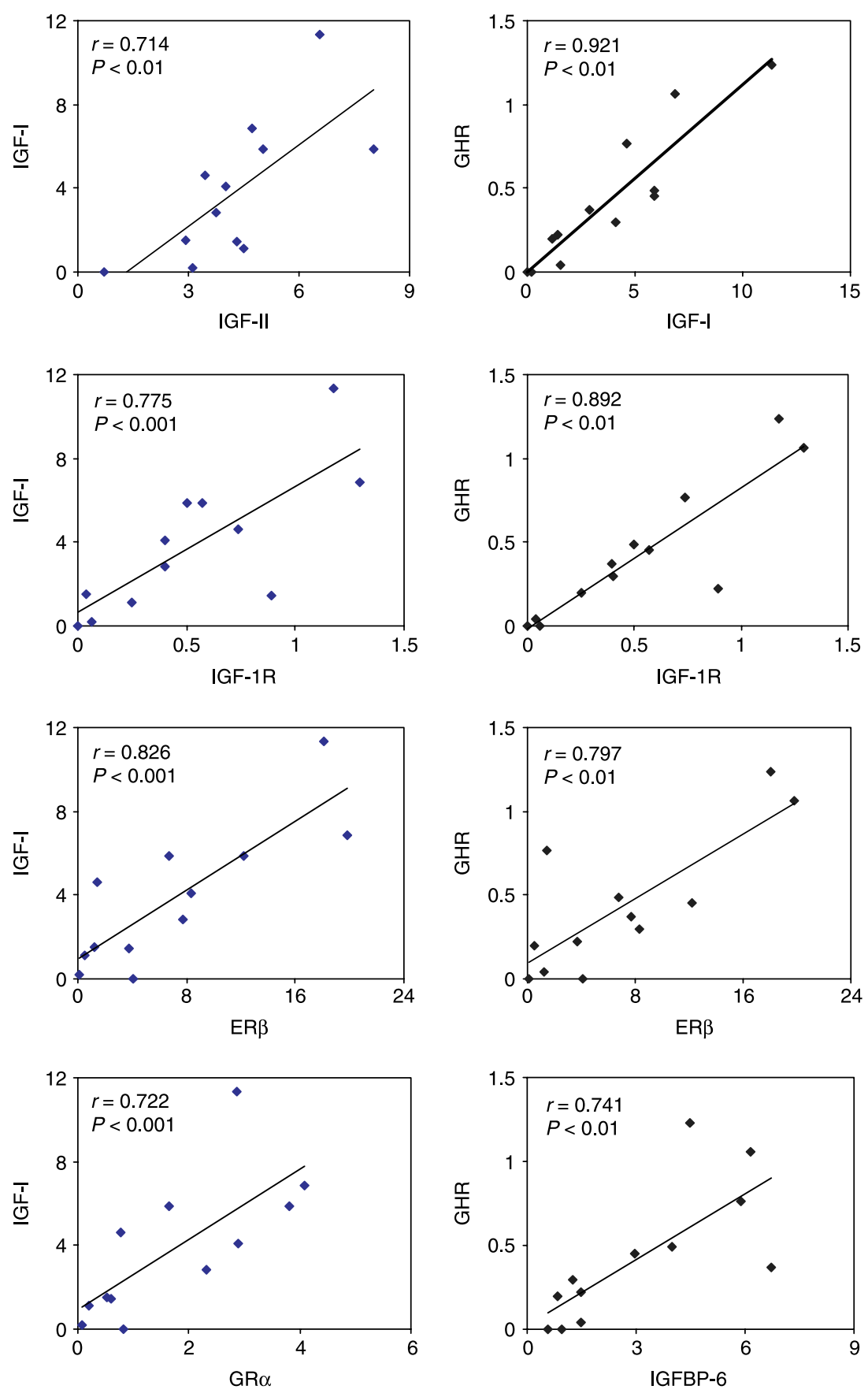

Figure 3 Quantitative gene expression relationships in the postpartum bovine oviduct. Expression values obtained by real-time PCR for all cows regardless of NEB status $(n=12)$. Significant associations (each $P<0.01$ ) between genes are shown for IGF-I ( $y$-axis; left) and GHR (y-axis; right).

and is also likely to be secreted into the lumen to influence development of the early embryo. The IGF- $1 \mathrm{R}$ is detectable within bovine embryos from the two-cell stage onwards (Lonergan et al. 2000).

The local expression of specific IGFBPs within individual tissues can provide information on IGF availability due to their intrinsic binding preferences. IGFBP-2 exhibits a relatively stronger affinity for IGF-II over IGF-I and likewise IGFBP-6 has an extreme (20- to 100-fold) preference for IGF-II (Bach 1999). Although the functional consequences of these relationships may vary, degradation of bound IGFBPs by proteolytic cleavage allows 'free $I \mathrm{GF}^{\prime}$ to gain access to their receptors. IGFBP-6 is more resistant to proteolysis and studies have shown that the effects of IGF-II are generally inhibited by the presence of IGFBP-6 (Grellier et al. 2002, Bach 2005). A relative reduction of oviductal IGFBP-6 and IGFBP-2 expression during SNEB may thus increase IGF-II signalling in the oviduct to counteract the low levels of circulating IGF-I during this time. This could act as a safety mechanism by allowing IGF-II to counteract the effects of NEB. Alternatively, as discussed 
below, this switch might have adverse consequences for fertility.

The concurrent reduction in IGFBP-2 and IGFBP-6 mRNA expression from opposing oviducts provides support for a systemic effect of NEB on the reproductive tract. Both IGFBP-2 and IGFBP-6 are sensitive to changes in reproductive hormones as shown by concurrent up-regulation during induced luteolysis in the bovine ovary (Neuvians et al. 2003). A temporal effect on uterine IGFBP-6 expression levels during the oestrous cycle has also been demonstrated in the sheep, with maximal concentrations around ovulation and the early luteal phase (Gadd et al. 2002). In the rat, a putative oestrogen receptor-binding site has been characterised in the promoter region of the IGFBP-6 gene (Zhu et al. 1993). Furthermore, ovariectomy can attenuate IGFBP-6 expression in bone and uterus (Higashi et al. 1996, Gadd et al. 2002), whereas administration of oestrogen increased IGF-II in embryonic cells (Kuhl et al. 2003). In the study presented here, however, there were no differences in either plasma oestradiol or oviductal $E R \alpha$ or $E R \beta$ expression according to $\mathrm{EB}$ status. Across treatments, there was a significant positive relationship between IGFBP-6 and expression of GHR, however, neither GH concentrations nor GHR differed between the groups. Another potential regulatory agent is retinoic acid, which increases IGFBP-6 mRNA synthesis in a number of cell lines (Bach 1999). Major changes in retinol metabolism occur in the immediate postpartum period in dairy cows (Horst et al. 1995, Van Merris et al. 2004), but were not assessed in the present study. In relation to IGFBP-2, there is considerable evidence that it is nutritionally responsive in certain tissues (Vicini et al. 1991, Clemmons 1997). In support of this, we recently showed that IGFBP-2 mRNA was down-regulated in granulosa cells of SNEB cows, further implicating the regulation of this binding protein by energy balance in reproductive tissues (Llewellyn et al. 2007).

In general, there was excellent agreement between the PCR and in situ hybridisation data, even though the results for each technique were obtained from the opposing oviducts in each cow. For the PCR analysis, oviducts had been frozen whole, whereas the latter technique offered the additional benefit that it was possible to distinguish the different regions. When data from both treatments were pooled, overall analysis indicated that IGF-II expression was stronger in the isthmus when compared with the remainder of the oviduct, while IGFBP-6 showed the opposite with the weakest expression in the isthmus. Furthermore, the relative reduction of IGFBP-6 in SNEB oviducts was specifically attributable to a change in expression in the ampullary region. Based on the in situ hybridisation data, IGFBP-3 expression levels were significantly higher in the isthmus relative to the infundibulum. In the liver, IGFBP-3 expression is regulated concurrently with IGF-I
(Woelfle \& Rotwein 2004) and therefore elevated levels of IGFBP-3 suggest a relationship with relatively high levels of uterine IGF-I as previously reported (Pershing et al. 2002). These differences in expression patterns along the oviduct are likely to reflect the different structure and functions of these two regions. The ampulla has more secretory tissue and is functionally important for sperm capacitation and fertilisation, whereas the isthmus contains more smooth muscle and is important for sperm transport (Ellington 1991, Hunter 2003).

Several studies have detected IGFBP-1 expression in human oviduct samples (Pfeifer \& Chegini 1994, Qiu et al. 2003), which was reduced in response to progesterone in culture (Davies et al. 2004). The undetectable levels of IGFBP-1 transcript in the bovine in this study and others (Winger et al. 1997, Pushpakumara et al. 2002) therefore appear to reflect species variation. The type-2 IGF receptor (IGF-2R) has not been studied in the oviduct previously and was only detected in 3 out of the 12 oviducts by quantitative RT-PCR. Transcript expression for other genes that can affect or mediate IGF transcription and signalling such as the receptors for insulin, IGF-I, GH, cortisol and oestrogen all remained unaltered by NEB.

In conclusion, the IGF system is relevant to many aspects of reproductive physiology and the involvement of these growth factors in the oviduct provides a potential link between nutritional status and fertility. We have shown that SNEB reduces both circulating IGF-I and the local expression of IGFBP-2 and IGFBP-6 (but not IGF-I or IGF-II) within the oviduct. This would predict enhanced IGF-II signalling, although conception rates are reduced in cows in NEB (Wathes et al. 2007). Many studies have investigated the effects of different culture systems for in vitro produced embryos. These have highlighted the fact that rates of embryo development and relative transcript abundance are both strongly influenced by the culture conditions (e.g. Thompson 2000). Furthermore, a suboptimal environment for as little as 1 day can perturb subsequent long-term development potential (Lonergan et al. 2003). IGF-II is an imprinted gene that mediates growth of early embryos and is known to have many profound effects on the formation of the foetus and placenta (FernandezGonzalez et al. 2007). Foetal calf serum has been a common constituent of embryo culture medium. It contains active IGF-II (Motoike \& Unsicker 1999), causes faster development to the blastocyst stage (Gutierrez-Adan et al. 2001), but ultimately results in birth of fewer normal calves (Farin et al. 2001). The fine control of energy metabolism by the embryo at this stage is also of crucial importance (Thompson 2000). In the light of our results, we speculate that embryos from cows in SNEB experience altered IGF signalling within the oviduct, which likewise has adverse effects on their development, contributing to the high rates of embryo mortality seen in high-yielding dairy cows. 


\section{Materials and Methods}

All chemicals and reagents were purchased from SigmaAldrich Company Ltd or VWR International Ltd (Poole, Dorset, UK) unless otherwise specified.

\section{Animals and tissue collection}

All procedures were carried out under license in accordance with the European Community Directive, 86-609-EC. From an initial pool of 24 Holstein-Friesian cows with an average previous lactation yield of $6477 \pm 354 \mathrm{~kg}, 12$ multiparous cows were randomly allocated 2 weeks prior to expected calving to either a MNEB or SNEB treatment, taking into account their parity, body condition score and previous lactation yield in a randomised block design. The mean parity numbers were 4.3 and 5.2 for the MNEB and SNEB groups respectively and the mean body condition scores (5-point scale with 0.25 increments) at calving were 3.5 and 4.0 , with an overall ranges of 3.0-4.5. The treatments began on the morning after the second or third milking following parturition. MNEB cows were fed grass silage ad libitum with $8 \mathrm{~kg} /$ day of a $21 \%$ crude protein dairy concentrate and milked once daily; SNEB cows were fed $25 \mathrm{~kg} /$ day silage with $4 \mathrm{~kg} /$ day concentrate and milked thrice daily. Similar treatment groupings were shown in a previous study to produce differences in EB in early lactation (Patton et al. 2006).

Energy balance was estimated as the difference between energy intake and the sum of energy for maintenance and milk production, based on measurements of milk yield, milk composition, liveweight and feed intake. The French NE system was used, where 1 unite fourragère lait (UFL) is the net energy for lactation equivalent of $1 \mathrm{~kg}$ standard air-dry barley (Jarrige 1989). The diameter of the first dominant follicle was determined for each cow from day 7 postpartum via daily transrectal ovarian ultrasonography (Aloka SSD-500 7.5 MHz transducer; Aloka Ltd, Tokyo, Japan). Cows were slaughtered on days 6-7 of the first follicular wave after calving. This design was chosen to collect tissue at a fixed time in relation to ovarian function to allow direct comparisons between tissues at the same stage of follicle development. Oviducts were collected at slaughter by manual separation from the ovary and cutting through the utero-tubal junction to separate from the uterus. Connective tissue was removed by dissection. The oviduct ipsilateral to the dominant follicle was frozen whole in liquid nitrogen for subsequent RNA extraction. For in situ hybridisation studies, the contralateral oviduct was coiled into a cardboard ring containing Cryo-M-Bed (Bright Instruments Co. Ltd, Huntingdon, UK) and placed on a sheet of metal cooled on dry ice. Once this had solidified, the rings were put into isopentane cooled in liquid $\mathrm{N}_{2}$ to freeze. Both sets of samples were then stored at $-80{ }^{\circ} \mathrm{C}$. The diameter of both uterine horns was measured $\sim 5 \mathrm{~cm}$ anterior to the bifurcation of the uterus, as an indicator of the process of uterine involution.

Blood samples were collected just prior to slaughter into lithium-heparin-primed vials and immediately placed on ice before centrifugation at $2000 \mathrm{~g}$ for $10 \mathrm{~min}$. Plasma was decanted and stored at $-20{ }^{\circ} \mathrm{C}$ for subsequent analysis. Samples of plasma were analysed for glucose, NEFA, BHB and urea using appropriate kits and an ABX Mira autoanalyser (ABX Mira, Montpellier, France). Concentrations of plasma IGF-I, insulin, GH and oestradiol were assayed as described previously (Taylor et al. 2004b, Fenwick et al. 2006, Llewellyn et al. 2007). Briefly, IGF-I concentrations were determined using the human OCTEIA IGF-I kit (IDS, Tyne and Wear, UK), the inter-assay coefficient of variation (CV) was $8.7 \%$ and the intra-assay CV values were 8.7 and $16.8 \%$ for samples with mean values of 81.5 and $4.7 \mathrm{ng} / \mathrm{ml}$ respectively. The sensitivity of the assay was $1.9 \mathrm{ng} / \mathrm{ml}$. Insulin concentration in plasma was assayed using a solid-phase RIA (Coat-a-count; Diagnostics Products Corp., Los Angeles, CA, USA). The inter- and intraassay $\mathrm{CV}$ values were 14.2 and $9.8 \%$ respectively. The minimum detectable limit of the assay was $1.6 \pm 0.03 \mu \mathrm{lU} / \mathrm{ml}$. A double antibody RIA was used for $\mathrm{GH}$ determination where bovine GH (a gift from Dr J Gong, Roslin Institute, Edinburgh) was used for iodination and preparation of the standard curve (Taylor et al. 2004b). The antiserum was raised in a guinea pig against bovine $\mathrm{GH}$ and was used at 1:10 000 dilution. The sensitivity of the assay was $1.6 \mathrm{ng} / \mathrm{ml}$. The intra-assay coefficient of variation was $12.9 \%$. Oestradiol concentrations were assayed using the Oestradiol MAIA assay kit (BioStat Diagnostic Systems, Stockport, UK). The intra-assay CV for samples with a mean of 1.1 and 4.6 oestradiol $\mathrm{pg} / \mathrm{ml}$ of serum were 5.8 and $7.3 \%$ respectively and the sensitivity was $0.2 \mathrm{pg} / \mathrm{ml}$. The intra-assay CV values for the same samples were 0.6 and $5.6 \%$ respectively. Cortisol concentrations were measured by RIA. Aliquots of $100 \mu$ l plasma were extracted with $3 \mathrm{ml}$ diethyl ether in glass tubes, the organic phase was dried down and the sample was reconstituted in $300 \mu$ l assay buffer. Next, $100 \mu \mathrm{l}$ aliquots of standard or extracted plasma were incubated with first antibody $(100 \mu$ l sheep anti-bovine cortisol; Diagnostics Scotland; diluted 1:1000 in assay buffer) and $\left[1,2,6,7-{ }^{3} \mathrm{H}\right]$-cortisol (Amersham Biosciences UK Ltd; $100 \mu \mathrm{l}, \sim 10000$ c.p.m.) overnight at $4{ }^{\circ} \mathrm{C}$. Separation was by dextran-charcoal. The intra-assay $\mathrm{CV}$ values for samples with means of 3.6 and 51.4 cortisol nmol// of plasma were 5.6 and $6.1 \%$ respectively and the sensitivity of the assay was $0.7 \mathrm{nmol} / \mathrm{l}$.

\section{Real-time RT-PCR}

Optimised PCR assays were used to detect transcripts for members of the IGF family including IGF-I/II, IGF receptors (IGF-1R/2R) and IGF-binding proteins (IGFBP-1/2/3/4/5/6), and also related factors including the receptors for IR-A/B, GHR, $\mathrm{GR} \alpha$ and $E R \alpha / \beta$. Primer sequence information is given in Table 4. A detailed description and applied conditions and protocols for these assays have been described and validated previously in bovine liver (Fenwick et al. 2006). Briefly, total RNA was extracted from frozen whole oviduct tissue ipsilateral to the dominant ovarian follicle and homogenised in TRI reagent (Molecular Research Centre Inc., Cincinnati, $\mathrm{OH}$, USA). Sample RNA concentration and purity was determined by spectrophotometry (NanoDrop Technologies Inc., Wilmington, DE, USA) where all samples had a 260/280 ratio of absorbance between 1.8 and 2.1. Any potential genomic DNA contamination was treated by incubating samples in the presence of DNase I in accordance with the manufacturer's instructions (Promega Corporation). Precisely, 
Table 4 Oligonucleotide primer sequence information used for real-time PCR assays.

\begin{tabular}{|c|c|c|c|}
\hline Gene & Primer sequence $\left(5^{\prime} \rightarrow 3^{\prime}\right)$ & GenBank accession & Product length $(b p)$ \\
\hline IGF-I & $\begin{array}{l}\text { Forward: AGTTGGTGGATGCTCTCCAGT } \\
\text { Reverse: CACTCATCCACGATTCCTGTC }\end{array}$ & X15726 & $115^{\mathrm{a}}$ \\
\hline IGF-1R & $\begin{array}{l}\text { Forward: GATCCCGTGTTCTTCTACGTTC } \\
\text { Reverse: AAGCCTCCCACTATCAACAGAA }\end{array}$ & X54980 & $101^{\mathrm{a}}$ \\
\hline IGF-II & $\begin{array}{l}\text { Forward: GCTTCTACTTCAGCCGACCAT } \\
\text { Reverse: GGCACAGTAAGTCTCCAGCAG }\end{array}$ & X53553 & $110^{\mathrm{a}}$ \\
\hline IGF-2R & $\begin{array}{l}\text { Forward: TACAACTTCCGGTGGTACACCA } \\
\text { Reverse: GGATTTCGCTAGCCTGGAGAG }\end{array}$ & AJ320234 & $111^{\mathrm{a}}$ \\
\hline IGFBP-1 & $\begin{array}{l}\text { Forward: TCAAGAAGTGGAAGGAGCCCT } \\
\text { Reverse: AATCCATTCTTGTTGCAGTTT }\end{array}$ & NM_174554 & $127^{\mathrm{a}}$ \\
\hline IGFBP-2 & $\begin{array}{l}\text { Forward: AGGGTGGCAAACATCACCT } \\
\text { Reverse: GAAGGCGCATGGTGGAGAT }\end{array}$ & NM_174555 & $120^{\mathrm{a}}$ \\
\hline IGFBP-3 & $\begin{array}{l}\text { Forward: ACAGACACCCAGAACTTCTCCTC } \\
\text { Reverse: GTTCAGGAACTTGAGGTGGTTC }\end{array}$ & NM_174556 & $102^{\mathrm{a}}$ \\
\hline IGFBP-4 & $\begin{array}{l}\text { Forward: GACCTTTACATCATTCCCATCC } \\
\text { Reverse: AAGCTTCACTCCCGTCTTCC }\end{array}$ & NM_174557 & $129^{\mathrm{a}}$ \\
\hline IGFBP-5 & $\begin{array}{l}\text { Forward: CAAGCCAAGATCGAAAGAGACT } \\
\text { Reverse: AAGATCTTGGGCGAGTAGGTCT }\end{array}$ & S52657 & $86^{\mathrm{a}}$ \\
\hline IGFBP-6 & $\begin{array}{l}\text { Forward: GGAGAGAATCCCAAGGAGAGTAA } \\
\text { Reverse: GAGTGGTAGAGGTCCCCGAGT }\end{array}$ & AY197339 & 100 \\
\hline IR-A & $\begin{array}{l}\text { Forward: TCCTCAAGGAGCTGGAGGAGT } \\
\text { Reverse: TTTCCTCGAAGGCCTGGGGAT }\end{array}$ & AJ488553 & 89 \\
\hline IR-B & $\begin{array}{l}\text { Forward: TCCTCAAGGAGCTGGAGGAGT } \\
\text { Reverse: TAGCGTCCTCGGCAACAGG }\end{array}$ & AJ320235 & 111 \\
\hline GHR & $\begin{array}{l}\text { Forward: ACTTGGGCTAGCAGTGACATTA } \\
\text { Reverse: TTCCTTTAATCTTTGGAACTGG }\end{array}$ & NM_176608 & $101^{\mathrm{a}}$ \\
\hline $\mathrm{GR} \alpha$ & $\begin{array}{l}\text { Forward: CTGGGGCCAATATAATTGGTAA } \\
\text { Reverse: TTCTGATCCTGCTGTTGAGAAA }\end{array}$ & DQ192585 & 124 \\
\hline $\mathrm{ER} \alpha$ & $\begin{array}{l}\text { Forward: TCAGGCTACCATTACGGAGTTT } \\
\text { Reverse: GTTTTTATCAATCGTGCACTGG }\end{array}$ & NM_001001443 & $120^{\mathrm{a}}$ \\
\hline$E R \beta$ & $\begin{array}{l}\text { Forward: CTTCGTGGAGCTCAGCCTGT } \\
\text { Reverse: GAGATATTCTTTGTGTTGGAGTTT }\end{array}$ & NM_174051 & $262^{\mathrm{a}}$ \\
\hline 18SrRNA & $\begin{array}{l}\text { Forward: CGGCGACGACCCATTCGAAC } \\
\text { Reverse: GAATCGAACCCTGATTCCCCGTC }\end{array}$ & AY779625 & 99 \\
\hline
\end{tabular}

Gene products analysed are IGF type I/II (IGF-I/II) and receptors (IGF-1R/2R), IGF-binding proteins 1-6 (IGFBP-1/2/3/4/5/6), insulin receptor type A/B (IR-A/B), growth hormone receptor (GHR), glucocorticoid receptor $\alpha(G R \alpha)$ and oestrogen receptor $\alpha \beta(E R \alpha \beta)$.

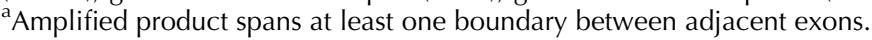

$1 \mu \mathrm{g}$ DNase-treated RNA was converted to cDNA in a randomly primed RT reaction using reagents and instructions supplied by Promega. Standards for quantitative PCR were prepared from purified PCR products that were quantified by spectroscopy (NanoDrop) and diluted over at least eight orders of magnitude. Standards and samples were quantified by PCR in $20 \mu \mathrm{l}$ reactions with SYBR green (Absolute QPCR SYBR green mix, ABgene, Surrey, UK) using the DNA Engine Opticon 2 (MJ Research Inc., Waltham, MA, USA). For all unknown oviduct samples, 50 ng reverse-transcribed RNA was added to each reaction in duplicate. To minimise variation, all samples included in each analysis were derived from the same RT batch, prepared under the same conditions throughout and were analysed on a single plate. A melting curve analysis was performed for each reaction to confirm specificity with previously sequenced amplification products. Data were recorded with the Opticon Monitor Analysis Software (V2.02; MJ Research, Inc.) and transcript expression levels were derived from standard curves of amplicons as described previously in bovine oviduct tissues (Bauersachs et al. 2004). Transcript levels for the ribosomal gene 18S were also analysed to account for sample variation through processing. Negative control samples were prepared as above minus the reverse transcriptase enzyme or cDNA to confirm the absence of genomic DNA and extraneous contamination respectively.

\section{In situ hybridisation procedure}

Serial sections of $10 \mu \mathrm{m}$ were thaw mounted onto SuperFrost Plus or POLYSINE microscope slides, fixed in $4 \%(\mathrm{w} / \mathrm{v})$ paraformaldehyde in $0.01 \mathrm{M} \mathrm{PBS}(\mathrm{pH} 7.0)$ for $5 \mathrm{~min}$ at room temperature, washed thrice with $0.01 \mathrm{M}$ PBS (3 min each), dehydrated in $70 \%$ (5 min) and 95\% (1 min) ethanol and stored at $4{ }^{\circ} \mathrm{C}$ in $95 \%$ ethanol prior to hybridisation. All probes used were singlestranded oligonucleotides of 45 bases in length previously validated in our laboratory on bovine ovary sections (Llewellyn et al. 2007; see Table 5). Briefly, the oligonucleotide probes (5 ng) were end labelled with $\left[{ }^{35} \mathrm{~S}\right] \mathrm{dATP}$ (Amersham Biosciences UK Ltd) using terminal deoxynucleotidyl transferase (Promega UK $\mathrm{Ltd})$ at $34{ }^{\circ} \mathrm{C}$ for $1 \mathrm{~h}$. Probe labelling efficiency averaged $38 \%$ (ranges $21-64 \%$ ). The labelled probe was diluted to a final concentration of 100000 c.p.m. $100 / \mu$ in hybridisation buffer $(50 \%(\mathrm{v} / \mathrm{v})$ deionised formamide, $4 \times$ sodium saline citrate $(\mathrm{SSC})$, $25 \mathrm{mM}$ sodium phosphate, $1 \mathrm{mM}$ sodium pyrophosphate, $5 \times$ Denhardt's solution, $0.2 \mathrm{mg} / \mathrm{ml}$ denatured salmon sperm DNA, $120 \mu \mathrm{g} / \mathrm{ml}$ sodium heparin, $100 \mu \mathrm{g} / \mathrm{ml}$ polyadenylic acid 
Table 5 Sense oligonucleotide probe sequences used for in situ hybridisation analysis and the exposure times for X-ray films and photographic emulsions.

\begin{tabular}{|c|c|c|c|c|c|}
\hline \multirow[b]{2}{*}{ Probe } & \multirow[b]{2}{*}{ Sequences } & \multirow[b]{2}{*}{$\begin{array}{c}\text { Accession ID } \\
\text { alignment }\end{array}$} & \multirow[b]{2}{*}{$\begin{array}{l}\text { Hybridisation } \\
\text { temperature }\left({ }^{\circ} \mathrm{C}\right)\end{array}$} & \multicolumn{2}{|c|}{ Exposure time (days) } \\
\hline & & & & X-ray film & Emulsions \\
\hline IGF-I & $\begin{array}{l}\text { Sense: 5'-TCACATCCTCCTCGCATCTCTTC- } \\
\text { TATCTGGCCCTGTGCTTGCTCG-3' } \\
\text { Antisense: 5'-CGAGCAAGCACAGGGCCAGATAGAAGA- } \\
\text { GATGCGAGGAGGATGTGA-3' }\end{array}$ & NM_001077828 & 45 & 7 & 42 \\
\hline IGF-II & $\begin{array}{l}\text { Sense: 5'-CCAGCGAGACTCTGTGCGGCGGG- } \\
\text { GAGCTGGTGGACACCCTCCAGT-3' } \\
\text { Antisense: 5'-AACTGGAGGGTGTCACCAGCTCCCCGCCG- } \\
\text { CACAGAGTCTCGCTGG-3' }\end{array}$ & NM_174087 & 52 & 4 & 30 \\
\hline IGF-1 $\mathrm{R}^{\mathrm{a}}$ & $\begin{array}{l}\text { Sense: 5'-CTCACGGTCATCCGCGGCTGGAAACTCTTCTA- } \\
\text { CAACTACGCCCTG-3' } \\
\text { Antisense: 5'-CAGGGCGTAGTTGTAGAAGAGTTTC- } \\
\text { CAGCCGCGGATGACCGTGAG-3' }\end{array}$ & XM_871496 & 42 & 4 & 42 \\
\hline IGFBP-1 & $\begin{array}{l}\text { Sense: 5'-GGAGAGCCTGGGCTCTGTTGGTGTGTC- } \\
\text { TACCCTTGGAGTGGGAAG-3' } \\
\text { Antisense: 5'-CTTCCCACTCCAAGGGTAGACACACCAACA- } \\
\text { GAGCCCAGGCTCTCC-3' }\end{array}$ & NM_174554 & 45 & 5 & $-{ }^{b}$ \\
\hline IGFBP-2 ${ }^{\mathrm{C}}$ & $\begin{array}{l}\text { Sense: 5'-GCGCCAGCCCCGAGCAGGTTGCAGACAATGGC- } \\
\text { GAGGAGCACTCTG-3' } \\
\text { Antisense: 5'-CAGAGTGCTCCTCGCCATTGTCTG- } \\
\text { CAACCTGCTCGGGGCTGGCGC-3' }\end{array}$ & NM_174555 & 45 & 4 & 42 \\
\hline IGFBP-3 & $\begin{array}{l}\text { Sense: 5'-GAGTCGGAAGAAGACCACAGCATGGGGAGCA- } \\
\text { CAGAGAACCAGGCT-3' } \\
\text { Antisense: 5'-AGCCTGGTTCTCTGTGCTCCC- } \\
\text { CATGCTGTGGTCTTCTTCCGACTC-3' }\end{array}$ & NM_174556 & 45 & 4 & 28 \\
\hline IGFBP-4 & $\begin{array}{l}\text { Sense: 5'-AAGACGGGAGTGAAGCTTCCGGGGGGCCTG- } \\
\text { GAGCCGAAGGGGGAG-3' } \\
\text { Antisense: 5'-CTCCCCCTTCGGCTCCAGGCCCCCCG- } \\
\text { GAAGCTTCACTCCCGTCTT-3' }\end{array}$ & NM_174557 & 45 & 5 & 42 \\
\hline IGFBP-5 & $\begin{array}{l}\text { Sense: 5'-CTACTCGCCCAAGATCTTCCGGCCCAAGCA- } \\
\text { CACCCGCATCTCCGA-3' } \\
\text { Antisense: 5'-TCGGAGATGCGGGTGTGCTTGGGCCGGAA- } \\
\text { GATCTTGGGCGAGTAG-3' }\end{array}$ & S52657 & 42 & 4 & 28 \\
\hline IGFBP-6 & $\begin{array}{l}\text { Sense: 5'-CTCTACGTGCCTAATTGTGACCATAGGGGCTTC- } \\
\text { TACCGGAAGCGG-3' } \\
\text { Antisense: 5'-CCGCTTCCGGTAGAAGCCCCTATGGTCA- } \\
\text { CAATTAGGCACGTAGAG-3' }\end{array}$ & NM_001040495 & 42 & 5 & 42 \\
\hline
\end{tabular}

${ }^{a}$ The bovine IGF-1R gene sequence is predicted, but the oligonucleotide probe shares $100 \%$ homology with the human IGF-IR gene (NM_000875.3). bAutoradiography revealed no hybridisation, so emulsions were not prepared. ${ }^{\mathrm{C} S e q u e n c e}$ is $97 \%$ homologous with the predicted bovine IGFBP-2 transcript.

and $100 \mathrm{mg} / \mathrm{ml}$ dextran sulphate) and $100 \mu \mathrm{l}$ was added to each slide. The slides were incubated in a humidified box overnight at 42,45 or $52{ }^{\circ} \mathrm{C}$ (Table 5). Following incubation, the slides were washed in a solution of $1 \times \mathrm{SSC}, 2 \mathrm{~g} / \mathrm{l}$ sodium thiosulphate at room temperature for 30 min followed by fresh $1 \times$ SSC, $2 \mathrm{~g} / \mathrm{l}$ sodium thiosulphate at $60{ }^{\circ} \mathrm{C}$ for $60 \mathrm{~min}$. Slides were rinsed successively for $1 \mathrm{~min}$ in solutions of $1 \times \mathrm{SSC}, 0.1 \times \mathrm{SSC}, 75 \%$ ethanol and $95 \%$ ethanol and air-dried before exposure to $\beta$-max hyperfilm (Kodak BioMax MR Film) for either 4 or 5 days.

All oviduct sections treated with a particular probe were hybridised in the same batch. Sense probes, which were identical in sequence to the respective mRNA targets, were always included as negative controls and any signal from these was regarded as non-specific. Each batch also contained an appropriate positive control tissue, based on previous studies. These were cross sections of uterus from an oestrous ewe for IGF-I and the type 1 IGF receptor (Stevenson et al. 1994), IGFBP-1 (Osgerby et al. 1999) and IGFBP-6 (Gadd et al. 2002); ovine placentome for IGF-II and
IGFBP-2, IGFBP-3 and IGFBP-4 (McMullen et al. 2005) and ovine intercotyledonary tissue for IGFBP-5 (Osgerby et al. 2004).

To aid cellular localisation of hybridised probes, selected slides were subsequently coated with photographic emulsion LM1 (Amersham Biosciences UK Ltd) according to the manufacturer's instructions and stored for 28, 30 or 42 days at $4{ }^{\circ} \mathrm{C}$ in darkness (Table 5). The slides were developed in $20 \%$ phenisol (ILFORD Imaging UK Ltd, Cheshire, England), fixed in 1.9 $\mathrm{M}$ sodium thiosulphate and counterstained with haematoxylin and eosin. All other slides were also stained with haematoxylin and eosin to aid identification of tissue region. The oviducts were characterised by tubal region (isthmus, ampulla and infundibulum) according to Hunter (2003).

\section{OD measurements}

The relative expression of $\mathrm{mRNA}$ for components of the oviduct IGF system was quantified from the autoradiographs using the 
public domain NIH ImageJ program (available through the $\mathrm{NIH}$ website - http://www.nih.gov), which calculated the average OD over the selected area of film based on a linear grey scale of 0.01-2.71. For each oviduct, the isthmus, ampulla and infundibulum regions were measured separately. Autoradiographs were scanned into a computer using a Hewlett-Packard Scanjet 5400c (Sheffield, UK) and OD measurements were recorded from digital images. Readings were obtained from at least two sections per tissue for each of the antisense (AS) and sense $(\mathrm{S})$ probes. The background OD, from a blank area of film, was also measured and subtracted from both AS and S OD measurements. Finally, the $S$ values were subtracted from AS values to give an average OD value for specific hybridisation (Perks et al. 1995). The detection limit was taken as an OD value of 0.01 .

\section{Statistical analysis}

Statistical analyses were performed using Statistical Package for the Social Sciences (SPSS for Windows, V13.0; SPSS Inc., Chicago, IL, USA). Data obtained by real-time PCR were expressed as $\mathrm{fg} / \mu \mathrm{g}$ RT RNA and differences at the time of tissue collection between MNEB and SNEB groups were analysed using an independent samples $t$-test. Levene's test was used to account for variance and if homogeneity was not achieved an unequal variance $t$-test was used.

For OD measurements from the in situ hybridisation studies, the fixed effects of treatment and oviduct region on the level of mRNA expression for each probe were analysed by Linear Mixed Model analysis. Cow was entered as a random effect. For this purpose, data from oviducts in which a particular probe showed no detectable specific hybridisation (OD of $<0.01$ ) were given an OD of 0.01 , which equated to the lower limit of detection.

Relationships between absolute levels of expression for all genes measured by real-time PCR were determined from values pooled across treatment groups. The spread of data was tested for normality using the Shapiro-Wilk test and square root transformations were made (if appropriate) before deriving Pearson correlations. For the correlation data, only those relationships with $P<0.01$ were considered. Results from all other analyses were considered statistically significant when $P<0.05$.

\section{Acknowledgements}

The authors would like to thank the valued contribution of the Teagasc Moorepark farm staff and the skilled technical assistance of Mr Joseph Larkin, Mr Jonathan Kenneally and Ms Niamh Hynes. This work was funded by the Wellcome Trust and the Irish National Development Plan. The authors declare that there is no conflict of interest that would prejudice the impartiality of this scientific work.

\section{References}

Bach LA 1999 The insulin-like growth factor binding protein-6: the 'forgotten' binding protein? Hormone and Metabolic Research 31 226-234.

Bach LA 2005 IGFBP-6 five years on; not so 'forgotten'? Growth Hormone and IGF Research 15 185-192.
Bar RS, Boes M, Clemmons DR, Busby WH, Sandra A, Dake BL \& Booth BA 1990 Insulin differentially alters transcapillary movement of intravascular IGFBP-1, IGFBP-2 and endothelial cell IGF-binding proteins in the rat heart. Endocrinology 127 497-499.

Bauersachs S, Rehfeld S, Ulbrich SE, Mallok S, Prelle K, Wenigerkind H, Einspanier R, Blum H \& Wolf E 2004 Monitoring gene expression changes in bovine oviduct epithelial cells during the oestrous cycle. Journal of Molecular Endocrinology 32 449-466.

Bauman DE \& Currie WB 1980 Partitioning of nutrients during pregnancy and lactation: a review of mechanisms involving homeostasis and homeorhesis. Journal of Dairy Science 63 1514-1529.

Beam SW \& Butler WR 1999 Effects of energy balance on follicular development and first ovulation in postpartum dairy cows. Journal of Reproduction and Fertility Supplement 54 411-424.

Boilard M, Reyes-Moreno C, Lachance C, Massicotte L, Bailey JL, Sirard M-A \& Leclerc P 2004 Localization of the chaperone proteins GRP78 and HSP60 on the luminal surface of bovine oviduct epithelial cells and their association with spermatozoa. Biology of Reproduction 71 1879-1889.

Buhi WC, Alvarez IM \& Kouba AJ 2000 Secreted proteins of the oviduct. Cells, Tissues, Organs 199 165-179.

Butler WR 2001 Nutritional effects on resumption of ovarian cyclicity and conception rate in post partum dairy cows. British Society for Animal Science Occasional Publication 26 133-145.

Carlsson B, Hillensjo T, Nilsson A, Tornell J \& Billig H 1993 Expression of insulin-like growth factor-I (IGF-I) in the rat fallopian tube: possible autocrine and paracrine action of fallopian tube-derived IGF-I on the fallopian tube and on the preimplantation embryo. Endocrinology 133 2031-2039.

Cigankova V, Krajnicakova H, Kokardova M \& Tomajkova E 1996 Morphological changes in the ewe uterine tube (oviduct) epithelium during puerperium. Veterinarni Medicina 41 339-346.

Clemmons DR 1997 Insulin-like growth factor binding proteins and their role in controlling IGF actions. Cytokine and Growth Factor Reviews 8 45-62.

Davies S, Richardson MC, Anthony FW, Mukhtar D \& Cameron IT 2004 Progesterone inhibits insulin-like growth factor binding protein-1 (IGFBP-1) production by explants of the fallopian tube. Molecular Human Reproduction 10 935-939.

Ellington JE 1991 The bovine oviduct and its role in reproduction: a review of the literature. Cornell Veterinarian 81 313-328.

Farin PW, Crosier AE \& Farin CE 2001 Influence of in vitro systems on embryo survival and fetal development in cattle. Theriogenology $\mathbf{5 5}$ 151-170.

Fenwick MA, Fitzpatrick R, Kenny DA, Diskin MG, Patton J, Murphy JJ \& Wathes DC 2006 Interrelationships between negative energy balance (NEB) and IGF regulation in liver of lactating dairy cows. Domestic Animal Endocrinology [in press] doi:10.1016/j.domaniend.2006.10.002.

Fernandez-Gonzalez R, Ramirez MA, Bilbao A, De Fonseca FR \& GutierrezAdan A 2007 Suboptimal in vitro culture conditions: an epigenetic origin of long-term health effects. Molecular Reproduction and Development $\mathbf{7 4}$ 1149-1156.

Fowden AL 1995 Endocrine regulation of fetal growth. Reproduction, Fertility, and Development 7 351-363.

Gabler C, Plath-Gabler A, Einspanier A \& Einspanier R 1998 Insulin-like and fibroblast growth factors and their receptors are differentially expressed in the oviducts of the common marmoset monkey (Callithrix jacchus) during the ovulatory cycle. Biology of Reproduction $\mathbf{5 8}$ 1451-1457.

Gadd TS, Osgerby JC \& Wathes DC 2002 Regulation of insulin-like growth factor binding protein- 6 expression in the reproductive tract throughout the estrous cycle and during the development of the placenta in the ewe. Biology of Reproduction 67 1756-1762.

Gier HT \& Marion GB 1968 Uterus of the cow after parturition: involutional changes. American Journal of Veterinary Research 29 83-96.

Giudice LC, Dsupin BA, Irwin JC \& Eckert RL 1992 Identification of insulinlike growth factor binding proteins in human oviduct. Fertility and Sterility 57 294-301.

Grellier P, Berrebi D, Peuchmaur M \& Babajko S 2002 The IGF system in neuroblastoma xenografts: focus on IGF-binding protein-6. Journal of Endocrinology 172 467-476. 
Gutierrez-Adan A, Lonergan P, Rizos D, Ward FA, Boland MP, Pintado B \& de la Fuente J 2001 Effect of the in vitro culture system on the kinetics of blastocyst development and sex ratio of bovine embryos. Theriogenology 55 1117-1126.

Higashi Y, Takenaka A, Takahashi SI \& Noguchi T 1996 Effect of protein restriction on the messenger RNA contents of bone-matrix proteins, insulin-like growth factors and insulin-like growth factor binding proteins in femur of ovariectomized rats. British Journal of Nutrition 75 811-823.

Horst RL, Reinhardt TA, Goff JP, Koszewski NJ \& Napoli JL 1995 9,13-Dicis-retinoic acid is the major circulating geometric isomer of retinoic acid in the periparturient period. Archives of Biochemistry and Biophysics 322 235-239.

Hunter RHF 2003 Physiology of the Graafian Follicle and Ovulation, Cambridge, UK: Cambridge University Press.

Jarrige J 1989 In INRAtion V2.7: Microsoft computer program of ration formulation for ruminant livestock. Eds J Agabriel, P Champciaux \& C Espinasse. Dijon, France: CNERTA.

Jones JI \& Clemmons DR 1995 Insulin-like growth factors and their binding proteins: biological actions. Endocrine Reviews 16 3-34.

Kuhl NM, Hoekstra D, De Vries H \& De Keyser J 2003 Insulin-like growth factor-binding protein 6 inhibits survival and differentiation of rat oligodendrocyte precursor cells. Glia 44 91-101.

Lai YM, Wang HS, Lee CL, Lee JD, Huang HY, Chang FH, Lee JF \& Soong YK 1996 Insulin-like growth factor-binding proteins produced by Vero cells, human oviductal cells and human endometrial cells, and the role of insulin-like growth factor-binding protein-3 in mouse embryo co-culture systems. Human Reproduction 11 1281-1286.

Leroy JL, Vanholder T, Opsomer G, Van Soom A \& de Kruif A 2006 The in vitro development of bovine oocytes after maturation in glucose and beta-hydroxybutyrate concentrations associated with negative energy balance in dairy cows. Reproduction in Domestic Animals 41 119-123.

Llewellyn S, Fitzpatrick R, Kenny DA, Murphy JJ, Scaramuzzi RJ \& Wathes DC 2007 Effect of negative energy balance on the insulin-like growth factor system in pre-recruitment ovarian follicles of postpartum dairy cows. Reproduction 133 627-639.

Lonergan P, Gutierrez-Adan A, Pintado B, Fair T, Ward F, Fuente JD \& Boland M 2000 Relationship between time of first cleavage and the expression of IGF-I growth factor, its receptor, and two housekeeping genes in bovine two-cell embryos and blastocysts produced in vitro. Molecular Reproduction and Development 57 146-152.

Lonergan P, Rizos D, Gutierrez-Adan A, Moreira PM, Pintado B, de la Fuente J \& Boland MP 2003 Temporal divergence in the pattern of messenger RNA expression in bovine embryos cultured from the zygote to blastocyst stage in vitro or in vivo. Biology of Reproduction 69 1424-1431.

Lucy MC, Jiang H \& Kobayashi Y 2001 Changes in the somatotrophic axis associated with the initiation of lactation. Journal of Dairy Science $\mathbf{8 4}$ E113-E119.

McMullen S, Osgerby JC, Milne JS, Wallace JM \& Wathes DC 2005 The effects of acute nutrient restriction in the mid-gestational ewe on maternal and fetal nutrient status, the expression of placental growth factors and fetal growth. Placenta 26 25-33.

Van Merris V, Meyer E, Duchateau L, Blum J \& Burvenich C 2004 All-trans retinoic acid is increased in the acute phase-related hyporetinemia during Escherichia coli mastitis. Journal of Dairy Science 87 980-987.

Motoike T \& Unsicker K 1999 Identification of a potent neurotrophic substance for ciliary ganglionic neurons in fetal calf serum as insulin-like growth factor II. Journal of Neuroscience Research 56 386-396.

Murphy LJ \& Friesen HG 1988 Differential effects of estrogen and growth hormone on uterine and hepatic insulin-like growth factor I gene expression in the ovariectomized hypophysectomized rat. Endocrinology 122 325-332.

Murray MK 1995 Epithelial lining of the sheep ampulla oviduct undergoes pregnancy-associated morphological changes in secretory status and cell height. Biology of Reproduction 53 653-663.

Nayak RK, Albert EN \& Kassira WN 1976 Fine structural changes of the porcine uterine tube epithelium during early and late pregnancy. American Journal of Veterinary Research 37 1421-1433.

Neuvians TP, Pfaffl MW, Berisha B \& Schams D 2003 The mRNA expression of the members of the IGF-system in bovine corpus luteum during induced luteolysis. Domestic Animal Endocrinology 25 359-372.
Osgerby JC, Gadd TS \& Wathes DC 1999 Expression of insulin-like growth factor binding protein-1 (IGFBP-1) mRNA in the ovine uterus throughout the oestrous cycle and early pregnancy. Journal of Endocrinology $\mathbf{1 6 2}$ 279-287.

Osgerby JC, Wathes DC, Howard D \& Gadd TS 2004 The effect of maternal undernutrition on the placental growth trajectory and the uterine insulinlike growth factor axis in the pregnant ewe. Journal of Endocrinology 182 89-103.

Patton J, Kenny DA, Mee JF, O'Mara FP, Wathes DC, Cook M \& Murphy JJ 2006 Effect of milking frequency and diet on milk production, energy balance, and reproduction in dairy cows. Journal of Dairy Science $\mathbf{8 9}$ 1478-1487.

Patton J, Kenny DA, McNamara S, Mee JF, O'Mara FP, Diskin MG \& Murphy JJ 2007 Relationships among milk production, energy balance, plasma analytes, and reproduction in Holstein-Friesian cows. Journal of Dairy Science 90 649-658.

Perks CM, Denning-Kendall PA, Gilmour RS \& Wathes DC 1995 Localization of messenger ribonucleic acids for insulin-like growth factor I (IGF-I), IGF-II, and the type 1 IGF receptor in the ovine ovary throughout the estrous cycle. Endocrinology 136 5266-5273.

Perry VE, Norman ST, Daniel RC, Owens PC, Grant P \& Doogan VJ 2002 Insulin-like growth factor levels during pregnancy in the cow are affected by protein supplementation in the maternal diet. Animal Reproduction Science 72 1-10.

Pershing RA, Lucy MC, Thatcher WW \& Badinga L 2002 Effects of BST on oviductal and uterine genes encoding components of the IGF system in lactating dairy cows. Journal of Dairy Science 85 3260-3267.

Pfeifer TL \& Chegini N 1994 Immunohistochemical localization of insulinlike growth factor (IGF-I), IGF-I receptor, and IGF binding proteins 1-4 in human fallopian tube at various reproductive stages. Biology of Reproduction 50 281-289.

Pushpakumara PG, Robinson RS, Demmers KJ, Mann GE, Sinclair KD, Webb R \& Wathes DC 2002 Expression of the insulin-like growth factor (IGF) system in the bovine oviduct at oestrus and during early pregnancy. Reproduction 123 859-868.

Qiu X, Sun X, Christow A, Stabi B \& Gemzell-Danielsson K 2003 Action of mifepristone on the expression of insulin-like growth factor binding protein-1 mRNA and protein during the early luteal phase in the human oviduct. Fertility and Sterility $80776-782$.

Radcliff RP, McCormack BL, Crooker BA \& Lucy MC 2003 Plasma hormones and expression of growth hormone receptor and insulin-like growth factor-I mRNA in hepatic tissue of periparturient dairy cows. Journal of Dairy Science 86 3920-3926.

Roche JF \& Diskin MG 2001 Resumption of reproductive activity in the early post partum period of cows. British Society of Animal Science Occasional Publication 26 31-42.

Schmidt A, Einspanier R, Amselgruber W, Sinowatz F \& Schams D 1994 Expression of insulin-like growth factor 1 (IGF-1) in the bovine oviduct during the oestrous cycle. Experimental Clinical Endocrinology 102 364-369.

Seki K, Rawson J, Eddy CA, Smith NK \& Pauerstein CJ 1978 Deciliation in the puerperal fallopian tube. Fertility and Sterility 29 75-83.

Sheldon IM, Lewis GS, LeBlanc S \& Gilbert RO 2006 Defining post partum uterine disease in cattle. Theriogenology 65 1516-1530.

Stevenson KR \& Wathes DC 1996 Insulin-like growth factors and their binding proteins in the ovine oviduct during the oestrous cycle. Journal of Reproduction and Fertility 108 31-40.

Stevenson KR, Gilmour RS \& Wathes DC 1994 Localization of insulin-like growth factor-I (IGF-I) and -II messenger ribonucleic acid and type 1 IGF receptors in the ovine uterus during the estrous cycle and early pregnancy. Endocrinology 134 1655-1664.

Taylor VJ, Beever DE \& Wathes DC 2003 Physiological adaptations to milk production that affect fertility in high yielding dairy cows. British Society of Animal Science Occasional Publication, vol 29, pp. 37-71. Nottingham, UK: Nottingham University Press.

Taylor VJ, Cheng Z, Pushpakumara PG, Beever DE \& Wathes DC 2004a Relationships between the plasma concentrations of insulin-like growth factor-I in dairy cows and their fertility and milk yield. Veterinary Record 155 583-588.

Taylor VJ, Beever DE, Bryant MJ \& Wathes DC 2004b First lactation ovarian function in dairy heifers in relation to pre-pubertal metabolic profiles. Journal of Endocrinology 180 63-75. 
Thissen JP, Ketelslegers JM \& Underwood LE 1994 Nutritional regulation of the insulin-like growth factors. Endocrine Reviews 15 80-101.

Thompson JG 2000 In vitro culture and embryo metabolism of cattle and sheep embryos - a decade of achievement. Animal Reproduction Science 60-61 263-275.

Tiemann U \& Hansen PJ 1995 Steroidal and growth factor regulation of $\left[{ }^{3} \mathrm{H}\right]$ thymidine incorporation by cultured endosalpingeal cells of the bovine oviduct. In Vitro Cellular \& Developmental Biology 31 640-645.

Vicini JL, Buonomo FC, Veenhuizen JJ, Miller MA, Clemmons DR \& Collier RJ 1991 Nutrient balance and stage of lactation affect responses of insulin, insulin-like growth factors I and II, and insulin-like growth factor-binding protein 2 to somatotropin administration in dairy cows. Journal of Nutrition 121 1656-1664.

Wathes DC, Taylor VJ, Cheng Z \& Mann GE 2003 Follicle growth, corpus luteum function and their effects on embryo development in the postpartum cow. Reproduction Supplement 61 219-237.

Wathes DC, Fenwick M, Cheng Z, Bourne N, Llewellyn S, Morris DG, Kenny D, Murphy J \& Fitzpatrick R 2007 Influence of negative energy balance on cyclicity and fertility in the high producing dairy cow. Theriogenology 68 S232-S241.

Watson AJ, Westhusin ME \& Winger QA 1999 IGF paracrine and autocrine interactions between conceptus and oviduct. Journal of Reproduction and Fertility 54 303-315.

Winger QA, de los Rios P, Han VK, Armstrong DT, Hill DJ \& Watson A 1997 Bovine oviductal and embryonic insulin-like growth factor binding proteins: possible regulators of 'embryotrophic' insulin-like growth factor circuits. Biology of Reproduction 56 1415-1423.
Wiseman DL, Henricks DM, Eberhardt DM \& Bridges WC 1992 Identification and content of insulin-like growth factors in porcine oviductal fluid. Biology of Reproduction 47 126-132.

Woelfle J \& Rotwein P 2004 In vivo regulation of growth hormonestimulated gene transcription by STAT5b. American Journal of Physiology. Endocrinology and Metabolism 286 E393-E401.

Xia P, Han VK, Viuff D, Armstrong DT \& Watson AJ 1996 Expression of insulin-like growth factors in two bovine oviductal cultures employed for embryo co-culture. Journal of Endocrinology 149 41-53.

Yding Andersen C 2002 Possible new mechanism of cortisol action in female reproductive organs: physiological implications of the free hormone hypothesis. Journal of Endocrinology 173 211-217.

Zapf J \& Froesch ER 1986 Insulin-like growth factors/somatomedins: structure, secretion, biological actions and physiological role. Hormone Research 24 121-130.

Zhu X, Ling N \& Shimasaki S 1993 Structural characterization of the rat insulin-like growth factor binding protein- 6 gene. Biochemical and Biophysical Research Communications 191 1237-1243.

Received 25 May 2007

First decision 27 July 2007

Revised manuscript received 3 October 2007

Accepted 17 October 2007 